\title{
Warburg Micro Syndrome- An Unusual Presentation with Brief Review of Literature
}

\author{
Sarah Aslam ${ }^{1}$, Mehwish Naeem ${ }^{1}$, Laraib Malik ${ }^{1 *}$, Sina Aziz ${ }^{1}$, Sadiq Mirza ${ }^{1}$ and Farheen Malik² \\ ${ }^{1}$ Abbasi Shaheed hospital, Pakistan \\ ${ }^{2}$ Dow medical College, Pakistan
}

Submission: February 07, 2020 Published: March 02, 2020

*Corresponding author: Laraib Malik, Abbasi Shaheed Hospital, Karachi, Pakistan

\begin{abstract}
Six months old child brought to our attention for developmental delay. Child came to our hospital for measles, on detailed history and examination, developmental delay noted at 6 months of age. He was operated for cataract at 4 months of age. At this time other anomalies including microcephaly, micro cornea, micro ophthalmia, anterior turning of ears, bilateral retractile testis, micro phallus was noted. X-ray lumbosacral spine showed spina bifida occulta. No family history of any genetic disorder. MRI revealed partial agenesis of corpus callosum, all of the mentioned findings are suggestive of a genetic disorder. Baby was therefore diagnosed as Warburg micro syndrome. It is therefore necessary to look for other syndromes too other than congenital rubella, which closely mimics Warburg syndrome, if a child presents with bilateral cataract only
\end{abstract}

Keywords: Microcephaly; Bilateral cataract; Warburg micro syndrome; Pakistan

\section{Introduction}

Warburg micro syndrome is a rare autosomal recessive disorder characterized by microcephaly, micro cornea, congenital cataract, developmental delay, hypogonadism, structural brain anomalies, large and asymmetric ears, low anterior hairline, hypotonia, absent speech, and overlapping toe [1]. In Pakistani family Warburg micro syndrome was first described in 1993 by Warburg [1]. This syndrome is characterized by mutation of four genes: RAB3GAP1, RAB3GAP2, RAB18, and TBC1D20. Among the above mentioned four genes, the most common mutation observed in Warburg micro syndrome are RAB3GAP1 and RAB3GAP2. Megarbane et al. (1999) reported four children (one male and three females) from a Shiite Muslim family from southern Lebanon [2]. This case report documents a baby of Sunni Muslim community, diagnosis of which was initially missed by a private hospital. When seen by our tertiary care hospital, history and detailed examination led to the diagnosis of a genetic disorder, Warburg micro syndrome.

\section{Case Presentation}

Six months old child brought to our attention for developmental delay. Child had both motor and intellectual developmental delay.
Social smile attained at 3 months of life, recognized mother at 4 months of age. Neck holding was not achieved at that time (6 months). He was the first born, only son of two healthy cousins. Parents are Sunni and Pakistani. Family history was unremarkable for genetic disorders. Mother had fever in 8 months of gestation but no history of rash, burning micturition or any other complains. Child was delivered via Caesarean section due to non-progression of labour. Birth weight was $2.5 \mathrm{~kg}$ and APGAR 8 at 1 minute and 9 at 5 minutes. Length at birth was $50 \mathrm{~cm}\left(50^{\text {th }}\right.$ centile $)$ and FOC $33 \mathrm{~cm}\left(10^{\text {th }}\right.$ centile). Child had bilateral cataract at birth. Rubella serology of both mother and baby were negative. Cataract was operated at 4 months of age with minimal improvement in vision. The child used to wear spectacles and was unable to see without it. On examination at 6 months his weight was $4 \mathrm{~kg}$, FOC was $37 \mathrm{~cm}$ (below $2^{\text {nd }}$ centile) and length $64 \mathrm{~cm}$. He had poor postural control. Child had microcephaly, child was wearing spectacles and responded poorly without it, hearing was normal, microphthalmia, microcornea, bulbous nose, broad nasal bridge, prominent ears, thin lips, long philtrum, prominent chin, micro penis $(1.5 \mathrm{~cm})$, bilateral retractile testis, two pits in sacral region, and delayed milestones. No organomegaly. In view of bilateral cataract and microcephaly, he had been evaluated for congenital 
rubella syndrome. Rubella serology was negative. Echo was also normal. Xray lumbosacral spine revealed spina bifida occulta. MRI brain detected diffuse cerebral atrophy with widening of sulci. Both lateral ventricles were widely separated with bull horn appearance, high riding third ventricle and interdigitation of gyri. Splenium of corpus callosum partially visualized. Partial agenesis of corpus callosum. Martsolf syndrome which mimics this syndrome has less severe ocular and neurologic symptoms. Genetic testing could not be done due to limited resources. However, typical clinical findings and the available investigations are suggestive of Warburg micro syndrome. Child is one year old now, neck holding still not achieved. Child has started making cheerful voices. Child often develops urine retention and on applying wet cloth passes urine. Passes urine 5-6 times a day with interrupted stream. Ultrasound identified right kidney hydronephrosis.

\section{Discussion}

Warburg micro syndrome is very rare, its exact incidence is not known [3]. Most of the cases have been observed in Muslim families, in males and in consanguineously married parents [3]. Our patient also belongs to Sunni Muslim community. And is the only son of related parents. Warburg was the first who described this syndrome in 1993 in three affected children, two siblings and a cousin from an inherent Pakistani family. However, there was no history of similar illness in the family. These children include microcephaly, hypogenitalism, cryptorchidism, borderline microphthalmia, micro cornea, congenital cataracts, optic nerve atrophy, and retinal dystrophy, these children have mental retardation and hypertrichosis, beaked nose with prominent nasal root, short philtrum, and prominent ears [3]. This baby also had microcephaly, microphthalmia, microcornea, congenital cataract and prominent ears. Warburg given it the term micro syndrome because of these combination of features [4]. Nassogne reported a male child having polymicrogyria and progressive motor neuropathy diagnosed as Warburg micro syndrome but having no seizures and hypogenitalism [4]. MRI of this baby showed partial agenesis of corpus callosum. Our patient also had no history of seizure. Ains worth highlighted that despite of early cataract treatment findings like microphthalmos, lens opacity and non-dilating atonic pupils, decreased vision due to cortical impairment occur. They proposed that congenital cataract with mental retardation is a common cause of this syndrome [5]. Our patient was operated for congenital cataract at four months of age. Despite cataract extraction visual perception of this child was poor. Therefore, child used to wear spectacles.

From the different case reports the combination of information regarding micro syndrome includes mental retardation, microcephaly, congenital cataract, micro cornea, microphthalmia, agenesis/hypoplasia of corpus callosum, and hypogenitalism. Hypo gonadotrophic hypogonadism leads to cryptorchidism, micropenis, labioscrotal fusion, and hypo plastic scrotum.
Additional systemic manifestations included axial hypotonia with evolving limb spasticity, and occasional seizures [6]. The reported case also had partial agenesis of corpus callosum, micropenis and bilateral retractile testis. Our patient also had two pits in the sacral region. Lumbosacral $\mathrm{x}$ ray spine showed spina bifida occulta. Patient had also developed urine retention and poor urinary strea. Ultrasound showed rightkidney hydronephrosis and acoustic mass. The diagnosis of this syndrome is based on clinical grounds, but there are certain syndromes similar to Warburg syndrome, these are CAMFAK syndrome (cataract, arthrogryposis, microcephaly, failure to thrive, and kyphoscoliosis) [6], CAMAK syndrome (cataract, arthrogryposis, microcephaly, and kyphoscoliosis) [7], COFS syndrome (brain atrophy with calcification, cataracts, micro cornea, joint contractures, and growth failure) [8], COCKAYNE syndrome (neurodegenerative disorder characterized by low birth weight, growth failure, brain demyelination with calcium deposits, cutaneous photosensitivity, cataract, and sensorineural hearing loss) [9]. Martsolf syndrome is very similar to Warburg but it has less severe defects of ocular and neurodevelopment. RAB3GAP1 mutations occur in Warburg micro while RAB3GAP2 mutation occur in Martsolf syndrome [10]. The reported patient had severe neurodevelopmental delay. Child used glasses because of poor vision without it.

\section{Conclusion}

The above-mentioned case is presented to highlight the importance of identification of micro syndrome in a patient who was first brought to medical attention for bilateral cataract only and was worked up in the view of congenital rubella only. Detailed examination can identify disorders. However, spina bifida occulta is an unusual finding in Warburg syndrome. Or is it a new syndrome?.

\section{References}

1. Online Mendelian Inheritance in Man, $\mathrm{OMIM}^{\circledR}{ }^{\mathrm{J}}$ ohns Hopkins University, Baltimore, MD. MIM Number: (600118). World Wide.

2. Mégarbané A, Choueiri R, Bleik J, Mezzina M, Caillaud C (1999) Microcephaly, microphthalmia, congenital cataract, optic atrophy, short stature, hypotonia, severe psychomotor retardation, and cerebral malformations: a second family with Micro syndrome or a new syndrome? J Med Genet 36: 637-640.

3. Warburg M1, Sjö O, Fledelius HC, Pedersen SA (1993) Autosomal recessive microcephaly, microcornea, congenital cataract, mental retardation, optic atrophy and hypogenitalism. Micro syndrome. Am J Dis Child 147: 1309-1312.

4. Nassogne MC, Henrot B, Saint-Martin C, Kadhim H, Dobyns WB, et al. Polymicrogyria and motor neuropathy in micro syndrome. Neuropediatrics 31: 218-221.

5. Ainsworth JR, Morton JE, Good P, Woods CG, George ND, et al. (2001) Micro syndrome in Muslim Pakistan children. Ophthalmology 108: 491-497.

6. Graham JM, Hennekam R, Dobyns WB, Roeder E, Busch D (2004) Micro syndrome: an entity distinct from COFS syndrome. Am J Med Genet A 128(3): 235-245. 
7. Scott-Emuakpor AB, Heffelfinger J, Higgins JV (1977) A syndrome of microcephaly and cataracts in four siblings: a new genetic syndrome? Am J Dis Child 131(2): 167-169.

8. Pena SD, Shokeir MH (1974) Autosomal recessive cerebrooculofacioskeletal (COFS) syndrome. Clin Genet 5: 285-293.
9. Nance MA, Berry SA (1992) Cockayne syndrome: review of 140 cases. Am J Med Genet 42(1): 68-84.

10. Abdel-Salam GM, Hassan NA, Kayed HF, Aligianis IA (2007) Phenotypic variability in Micro syndrome: report of new cases. Genetic Counsel 18 423-435.

\section{Your next submission with Juniper Publishers} will reach you the below assets

- Quality Editorial service

- Swift Peer Review

- Reprints availability

- E-prints Service

- Manuscript Podcast for convenient understanding

- Global attainment for your research

- Manuscript accessibility in different formats

( Pdf, E-pub, Full Text, Audio)

- Unceasing customer service

Track the below URL for one-step submission https://juniperpublishers.com/online-submission.php 